The University of San Francisco

USF Scholarship: a digital repository@ Gleeson Library |

Geschke Center

Sociology

College of Arts and Sciences

$5-2001$

\title{
Normal Sins: Sex Scandal Narratives as Institutional Morality Tales
}

Joshua Gamson

University of San Francisco, gamson@usfca.edu

Follow this and additional works at: http://repository.usfca.edu/soc

Part of the Sociology Commons

\section{Recommended Citation}

Gamson, Joshua, "Normal Sins: Sex Scandal Narratives as Institutional Morality Tales" (2001). Sociology. Paper 3.

http://repository.usfca.edu/soc/3

This Article is brought to you for free and open access by the College of Arts and Sciences at USF Scholarship: a digital repository @ Gleeson Library | Geschke Center. It has been accepted for inclusion in Sociology by an authorized administrator of USF Scholarship: a digital repository @ Gleeson

Library | Geschke Center. For more information, please contact repository@usfca.edu. 


\title{
Normal sins: Sex scandal narratives as institutional morality tales
}

\section{Joshua Gamson}

Social Problems; May 2001; 48, 2; ABI/INFORM Global

pg. 185

\section{Normal Sins: Sex Scandal Narratives as Institutional Morality Tales}

\author{
JOSHUA GAMSON, Yale University
}

\begin{abstract}
Sex scandals are widely assumed to be tales of individual transgression, serving as reminders of the normative sexual order. This paper, a qualitative multiple-case comparison of three contemporary media-conveyed sex scandals narratives, suggests otherwise. Drawing on extensive news documents, the study considers three stories, each revolving around the same sexual behavior, but each playing out in a different institutional environment: televangelist Jimmy Swaggart's encounter with prostitute Debra Murphree in 1988, actor Hugh Grant's encounter with prostitute Divine Brown in 1995, and presidential advisor Dick Morris' encounter with prostitute Sherry Rowlands in 1996. On the one hand, within the same overarching narrative, different themes become dominant. In one case, the relationship with a prostitute gives rise to a story primarily focused on hypocrisy; in another, to a story focused mainly on recklessness; in the last, to a story focused mainly on amorality and disloyalty. On the other hand, the stories share a common dynamic and common themes: the discussions of sexual "misbehavior." which kick each story into gear, are rapidly edged out by themes of inauthenticity, and by suggestions that hypocrisy, risk, or disloyalty are facilitated by the man's particular institutional environment. Sex scandal stories, rather than remaining stories of individual sexual transgression, are transformed into institutional morality tales. Such a pattern. the author argues, results from pronounced needs on the part of mainstream media organizations to both mimic and distinguish themselves from tabloid media, and from journalists" interest in transforming "soft" into "hard" news stories. While they draw on and buttress familiar "cultural givens" about masculine sexuality, these scandal stories offer an even more theoretically challenging twist: an unexpected cultural reversal, in which sexual "sins" as narrated by American news media, reveal not individual, but institutional pathologies; not a normative order, but institutional decay.
\end{abstract}

In the past two decades alone, national politicians have been accused of affairs with female and male prostitutes and pages, fondling or groping others and exposing themselves, attending drug-and-sex parties, having intercourse with minors, and allowing sex rings to operate from their apartments. Entertainers have been revealed to masturbate in movie theaters, solicit transvestite prostitutes, make sex videos of themselves, and simulate lesbian sex for photographers. Religious leaders have been accused of homosexual orgies with young Brazilian men, liaisons with church secretaries, and wife swapping, while similar charges have erupted in the military and in the academy. Sex scandals, in which sexual activities (demonstrated or alleged) of public figures are widely broadcast, with an ensuing public discussion of these activities as "transgressions of certain values, norms, or moral codes" (Thompson 1997:39), have a long history in Anglo-American culture.

Historians provide rich accounts of scandals in Victorian Britain (W. Cohen 1996; Fisher 1995; Israel 1997) and 19th-century United States (Basch 1993; Fox 1999; Marszalek 1997; Schudson 1976), joined by occasional analytical accounts of individual 20th-century sex scandals (Castor 1991; Erni 1998; Fine 1997; Stoker 1993) and non-scholarly books surveying the territory (Anger 1975; Collins 1998). Yet popular accounts of sex scandals tend to treat "each

I am grateful for thoughtful comments on earlier drafts of this paper from William Gamson, Wendy Griswold, Abigail Saguy, John Summers, and several excellent Social Problems reviewers. Direct correspondence 10: Joshua Gamson, Department of Sociology. Yale University, P.O. Box 208265, New Haven, CT 06520-8265. E-mail: joshua.gamson@ yale.edu.

SOCIAL PROBLEMS, Vol. 48, No. 2, pages 185-205. ISSN: 0037-7791

(C) 2001 by Society for the Study of Social Problems, Inc. All rights reserved.

Send requests for permission to reprint to: Rights and Permissions, University of California Press,

Journals Division, 2000 Center St., Ste. 303, Berkeley, CA 94704-1223. 
new case as if it sprung up sui generis" (W. Cohen 1996:2) and sociologists are remarkably reluctant to confront sex scandal stories as significant cultural phenomena. This is especially odd, given that, as a small body of theoretical literature on scandals notes (Lull and Hinerman 1997: Merry 1984; Thompson 1997) scandals comprise a cultural genre that is quite distinct and by now familiar: as outlined by William Cohen, the narrative is built "on the tripartite juridical model of plaintiff, defendant, and jury" in which "an accuser exposes an indiscretion or iniquity in the life of an accused and broadcasts that secret for public consumption and the accused responds with denial" (W. Cohen 1996:7-8). One can discern, both within others' accounts of sex scandals and in the cases considered in what follows, an increasingly common set of moments in mass-mediated sex scandals following a common scandal script: accusation or revelation, broadcast, denial and/or confession-and frequently, a comeback or attempted comeback. Just how that script is constructed and what it might be doing, remains understudied.

Perhaps the sparse sociological consideration of sex scandals can be attributed to their apparent transparency: they appear to be simply barometers of sexual moralities, moments in which a society reminds itself what is and is not acceptable sexual behavior by punishing with public humiliation and the risk of status loss, those highly visible people caught doing the unacceptable stuff. And such a perspective is not exactly wrong. Behavior can easily be irritating roguery in one generation or country and sexual harassment in another, something people do in public in one century and something seen as behind-closed-doors activity in another, shocking and immoral in one decade and merely a bit unseemly a lew decades later or earlier.

Yet, while sex scandal narratives are, generally speaking, carriers of social attitudes toward sexual morality, treating them exclusively as such can keep hidden their more puzzling and revealing aspects. To begin with, the actual sex they consider is strikingly banal. As Michael Schudson argues, and as I will further demonstrate, "the scandalous act rarely involves anything exotic" and "of all the elements of a sex scandal, the scandalous act itself may be the least important" (Schudson 1976:51). Historically, moreover, sexual conservatism (or for that matter, sexual liberalism) and the prevalence of sex scandals do not line up consistently (Summers 2000).

Even more tellingly, when one looks at nationally publicized sex scandals across institutional settings in the same time period-as does the current study-holding the national sexual culture roughly constant, it is hard to retain the notion that sex scandals are simply snapshots of society-wide sexual values or values-conflicts. When it comes to sex scandal narratives, a quick historical check suggests that the emergence of a scandal story is tightly tied to its institutional location. As John Summers shows, for instance, even as the sexual activities of movie stars and sports heroes were being "relentlessly probed and devoured" in early 20th-century mass culture's "agitation against Victorian values" (Summers 2000:11)-with Charlie Chaplin and Fatty Arbuckle embroiled in high-profile sex scandals, for instance (Anger 1975; Fine 1997)—politicians were exempted from scrutiny, pursuing "illicit sexual pleasures . . evidently unafraid that a demand for accountability might lead to opprobrium" (Summers 2000). And amidst all the strange, juicy details of contemporary sex scandals-the cigars as sex toys, the biting and the toe sucking, the steamed-up car windows, and so on-are the noteworthy facts that behavior that is scandalous in one institutional environment barely gets a mention in another. Indeed, what is underplayed in both the limited scholarly work and the voluminous popular commentary on scandal, is the simple recognition that the scandal script unfolds, as Gary Alan Fine asserts, "within an institutional structure (e.g., politics, business, the media)

1. At a general level, James Lull and Stephen Hinerman suggest major criteria for delineating scandal from nonscandal: "social norms reflecting the dominant morality must be transgressed," and those transgressions must be carried out by specific persons in an exercise of their own desires or interests; the perpetrators must be identified and shown to have acted intentionally or recklessly, and to be held responsible for their acions, which then have "differential consequences" for those involved; the revelations must be widely circulated by communications media and "effectively narrativized into a story which ... inspires widespread interest and discussion" (Lull and Hinerman 1997:1 1-13). 
and, more significantly, must be said to characterize that structure" (Fine 1997:297; see also Jacobs 1998).

Institutions matter in another way as well. Put simply, sex scandal stories are selected and conveyed by media professionals and, as scholars have routinely shown (e.g., Bennett 1996; Gitlin 1983), institutional mediation-the specific ways reporting is organized, the structure of social relations between media workers and those in other institutional worlds (religious, political, entertainment, and so on)-affects the storytelling. Again, historical evidence offers an anchor. When, for example, a period of regular public exposure about the sexual lives of politicians (e.g., in the 1884 presidential campaign, Grover Cleveland was subjected to accusations of "habitual immoralities with women" and of fathering an illegitimate child) gave way to "reticence and insulation" by the end of the 19th century (e.g., while Warren Harding's extramarital affairs were an open secret among politicians and journalists, "neither journalists nor rival Democrats disclosed his philandering to the voting public"), it gave way, in large part, thanks to the professionalization of journalism (Summers 2000). The "promise of reticence," Summers suggests, "permitted elite reporters to get closer to the instruments of government power," offering "an expedient means by which reporters could establish themselves as experts in an increasingly segmented, hierarchical society" (Summers 2000:18, 20). Although my focus is on scandal storytelling rather than on the selection or suppression of scandals, the lesson is useful: What is revealed in sex scandal discourse is not simply societal norms-sexual or other, institution-specific, or not-but also the institutional operations and relations of news media.

Taking the institutional context of scandals into account requires, then, documenting and analyzing how sex scandal discourse varies from one institutional location to another, and to what degree and in what ways the stories told concern institutions themselves; it further requires a consideration of how media institutional practices shape sex scandal scripts. ${ }^{2}$ In this comparative "instrumental case study" (Stake 2000:437), ${ }^{3}$ I therefore, examine the media coverage of three different U.S. sex scandals that received major national attention during an eight-year time span, each alleging the same behavior (sexual relations between a man and a female prostitute), each involving men who were public figures before the scandal, and women who were not, and each set in a different institutional environment: in the realm of religion, televangelist Jimmy Swaggart's encounter with prostitute Debra Murphree in 1988; in the entertainment arena, actor Hugh Grant's encounter with prostitute Divine Brown in 1995; and in the political sphere, presidential advisor Dick Morris' encounter with prostitute Sherry Rowlands in 1996. I rebuild and analyze these media-processed scandal stories based on all full-text coverage available through the online databases Academic Universe and Academic Search, including newspapers, magazines, and television transcripts, all of which are from mainstream regional and national publications, wire services, or programs. After duplicates and items of fewer than 100 words were eliminated, this yielded a total of 59 documents for the Swaggart case, 69 documents for the Grant case, and 95 documents for the Morris case. ${ }^{4}$ (These documents were supplemented by coverage of the scandals in "men's maga-

2. In a more general sense, I am here following the lead of sociologists of culture who insist on specilying links between institutional and discursive analyses of cultural phenomena (Griswold 1987), calting attention to the mutual influence of institutional environments and culural scripts, "whe ways in which enduring social institutions are explicit ly constructed out of a complex process of negotiation and contestation over cultural meanings" (Mohr 1998:350), and the ways those institutions themselves shape cultural meanings.

3. As Diane vaughan has recently noted, qualitative case comparison "of similar events, activities, or phenomena that occur in distincty different social settings" is a promising means toward theorizing that links cultural and structural levels of analysis (Vaughan 1999). Like any such comparison, this one is necessarily loose, since every scx scandal has its own idiosyncratic cast of characters and particular history. Still, one can safely assume that both the professional workings of and cultural attitudes toward prostitution did not make great shifts, and that the operation of news media did not change dramatically, in this brief time period. 
zines" such as Penthouse, in which the women of scandal often eventually appear [Gamson 2001].) Data analysis proceeded through an inductive coding process much like that of "grounded theory" (Charmaz 2000; Glaser and Strauss 1967; Ryan and Bernard 2000). My search was for the limited number of dominant frames-"schemata of interpretation," in the language of media discourse analysts (Binder 1993; Snow, et al. 1986)-contained in the media telling of and commentary on each story, and a chronological account of the movement from one theme to another over the course of the scandal's career. The documentary paper trail I follow and use is most accurately understood as stories told by one set of institutional elites (journalists, editors, etc.) about members of other institutional elites (people at the center of religious, political, and entertainment "industries"), with an eye towards those consuming the media product.

The findings dramatically bear out the significance of both institutional location and mediation. On the one hand, I will demonstrate that within the same overarching scandal narrative, quite different themes come to the fore-in one case, the relationship with a prostitute gives rise to a story primarily focused on hypocrisy; in another, to a story focused mainly on risk-taking; in the last, to a story focused mainly on disloyalty. On the other hand, in each case, discussions of sexual "misbehavior" kick the story into gear and are then mostly sidelined, edged aside by discussions of the possibility that hypocrisy, risk, or disloyalty are actually facilitated by the institutional environment in which the scandalous man operates. Sex scandal stories, far from being lessons about individual sexual transgression, morph into institutional morality tales. This shared leature of sex scandal narratives is best understood, I argue, through an analysis of media behaviors: it results from pronounced needs on the part of mainstream media organizations to both mimic and distinguish themselves from tabloid media, and from journalists' interest in transforming "soft" into "hard" news stories. Given the wellknown tendency in American culture toward individualist and away from structural frames and the well-known tendency in sociology toward interpreting tales of "sin" as reminders of the normative order, such a dynamic is especially striking. While drawing on and buttressing "cultural givens" about masculine sexuality, these scandal stories offer a theoretically challenging twist: an unexpected cultural reversal, in which sexual "sins" reveal not individual, but institutional pathologies; not a normative order, but institutional decay.

\section{Jimmy Swaggart: Normal Hypocrisy}

Undoubtedly the most famous image from the 1988 scandal over televangelist Jimmy Swaggart's visits to a New Orleans prostitute was his sobbing, televised, "I have sinned!" confession at Swaggart's own World Faith Center in Baton Rouge. While a spokesman for the Assemblies of God, the parent church which was then investigating the charges of sexual misconduct against Swaggart and considering various punishments, suggested that the preacher had shown "true humility and repentance" (W. King 1988b), most secular commentators were less impressed. "The sin for which Swaggart has been forgiven is the sexual transgression for which he has apologized," columnist Richard Cohen wrote in The Washington Post. "The sin

4. Most of the documents were from newspapers and magazines, although the sample also included television transcripts (4 in the Swaggart case, 9 in the Grant case, and 11 in the Morris case). Most were reports, but the sample also included a small number of interviews ( 1 in the Swaggart case, 3 in the Grant case, and 8 in the Morris case), and a significant number of commentary documents ( 7 in the Swaggart case, 22 in the Grant case, and 25 in the Morris case): because I take the story to be framed through both reporting and commentary, I do not separate the two in the analysis. Although these data provide quite a comprehensive picture of mainstream media framing of the sex scandals, their limitations should also be noted. They do not provide elaborate information about how tabloid press covers these scandals (though the "legitimate" press often reports on, and laments, tabloid coverage), or how media serving particular communities (e.g., African American press, Christian press, etc.) cover them. A comparison across these different types of outlets, although beyond the scope of this paper, would be extremely useful. 
of hypocrisy is a different matter. For that we hear no contrition and no apology from Swaggart" (Cohen 1988). The dominant media frame through which the Swaggart story was typically told was much less about the exposure of scandalous sexual behavior per se than about the exposure of hypocrisy-and along with it, about a turf war, in which feuding preachers use scandal as a weapon in their fight for a share of the religion market. Indeed, as the story progressed, these two frames, joined later by discussions of religious theatricality, overshadowed considerations of sexual norms, focusing attention, instead, on the workings of market-centered religious institutions.

Of course, sex was an excellent trigger for and carrier of the hypocrisy tale. It is no secret that news organizations perceive sexual stories as attention-grabbers, and for the two weeks after the story broke in late February of 1988, reporters regularly took the opportunity to describe the prostitution world to which Swaggart regularly traveled, Arline Highway, "a seedy strip of no-tell motels, their neon lights flashing adult movies, water beds and rooms by the hour" (Harris 1988a) where Debra Murphree said she "performed obscene acts" for the "sex-crazed" preacher ("Swaggart Led Sex-Crazed Life" 1988). But while early reports noted that the investigation by the Assemblies of God focused on "sexual morals charges" and "adultery" (Isikoff and Harris 1988), the morality of prostitution, and of married men visiting prostitutes, or even of extramarital sex, was almost never the frame of mainstream media stories and commentary."

Instead, what animated the stories was the dramatic contrast between Swaggart's own routine, holier-than-thou lashings of other preachers' sexual immorality and the photographs of him in a sweat suit in the Arline Highway parking lo1. It was Swaggart who had urged the investigation of Jim Bakker on charges of adulterous and bisexual behavior, news stories reminded readers ("The Human Comedy" 1988; Isikoff and Harris 1988; P. King 1988), and who had preached against false prophets, "pompadoured pretty-boys with their hair done and their nails done who call themselves preachers" (Dart 1988a); it was he who warned readers of his book, Straight Answers to Tough Questions, the Los Angeles Times pointed out, against sexually corrupting activities such as dancing, mixed swimming, movies, masturbation, and pornography (Dart 1988b). "Many of Swaggart's holier-than-thou pieties could come back to haunt him now that the worm has turned," Newsweek reported early on (Hackett 1988; see also Schwartz 1988). Prostitute visits were scandalous not so much because of sexual immorality, but because of the hypocrisy they revealed.

If sexual revelations were the means through which a story of hypocrisy was initially car ried-the story of a heavy-handed moralist foiled by the very sexual activities he chastised in others-the sexual aspects were rarely the primary subject of nationally publicized discussion, and, except for a gloating, self-justifying Penthouse spread, they mostly disappeared. ${ }^{6}$ (Swaggart himself never specified his "sins," though Murphree emerged early on with her claim that he

5. Sexual morality may in tact have been a more frequent theme within the religious press (Stepp 1988), and sexual behavior was a primary focus in the few interviews conducted with Murphree herself (CNN $1991 \mathrm{~b}$ ).

6. In fact, even in a Penthouse article and photo spread featuring Debra Murphree, the "siren of New Orleans's secdy Arline Highway," in which sex was of course central, sextlality was featured in the service of a hypocrisy narrative. The article, which recounts the rivalry between Swaggart and Gorman, and includes the explicit, pornographyderived scxual requests from Swaggart to Murphree "He wanted me to have a dress on, and I'd pretend that he's not there, and then he'd come sneak up and peek up my dress," "He'd ask me if I'd ever let anyone screw my daughter," and so oni, begins with a passage from Matthew warning against "false prophets, which come to you in sheep's clothing, but inwardly they are ravening wolves" (Harris and Berry 1988:104). That the priority is on driving home hypocrisy rather than eliciting sexual fantasy is accentuated by the "Debbie Does Swaggart" pictorial, which contrasts sharply with the soft-focus, full-color, lacy Pet-of-the-Month centerfold layout just before it: a somewhat chunky Murphree poses, in large tinted sunglasses and little makeup, in stark black-and-white photos that recreate the positions for which Swaggart paid. The pictorial begins by counter-posing two quotes. "Pornography titillates and captivates the sickest of the sick and makes them slaves to their own consuming lusts," says the first, from Swaggart's Rape of a Nation. The second is allegedly from Swaggart to Murphree: "Pull down your panties. . . Pull your panties up your crack, like a magazine I've seen. . . Get on your hands and knees with your ass in the air" "Debbie Does Swaggart" 1988:107). (One of the writers of this story, Art Harris, also covered the scandal for The Washington Post, and later for CNN.) 
had paid her to pose in various positions culled from pornographic magazines while he mastur bated.) As the story progressed, news coverage quickly focused not on Swaggart as a renegade hypocrite, but on what the scandal revealed about the profession and institution of televangelism.

As soon as it erupted, in fact, the scandal began to be placed in a context that made hypocrisy seem a rather unsurprising part of Swaggart's world, in which public moralizing was routine, performance was part of the job, financial stakes were high, and rivalries were numerous. The hypocrisy-revealed frame was quickly joined by a second major frame, that of a larger "holy war," as Newsweek called it (Hackett 1988; see also Mandel 1988), in which the Swaggart investigation was one battle. In this frame, Swaggart and his fall were taken as representative of televangelism's workings, its product rather than its exception. "The turmoil in [Swaggart's] ministry in this year of wild upheaval in television evangelism," as a New York Times report suggested, "may be the most telling indicator to date of the tensions that threaten to transform the billion-dollar world of the electronic church" (Applebome 1988).

Many accounts told the story of a religious "industry" - "wealthy spiritual empires" that "nurture gold-plated lifestyles" (Rosellini 1988)_comprised of money-and-power-hungry backstabbers. Swaggart sat at the head of a "\$156 million-a-year global television empire," The Washington Post reported in its first article on the scandal (Isikoff and Harris 1988; see also: Rosellini 1988; Dart 1988a), living, The New York Times reported, in “a $\$ 2.4$ million house with security fence, electronic sensors, and columned whirlpool bath fed by a faucet in the form of a golden swan" (W. King 1988a). In the "holy war" frame, the fight for control of such riches is exactly what triggered the scandal in the first place: "a rival evangelist" (W. King 1988b). Marvin Gorman, who had filed a 1987 lawsuit against Swaggart for spreading rumors about Gorman's own sexual misconduct, effectively ending Gorman's ministry (Hackett 1988), went in search of the "sweet taste of vengeance," The Washington Post suggested, and found it on Arline Highway (Harris 1988a; see also: Harris 1988b; "The Human Comedy" 1988). Others in this competitive marketplace, most notably Rev. Jerry Falwell, quickly staked claims in the "turf war" by calling for further investigations (Mandel 1988).

If high-stakes rivalry characterized coverage of the moment of revelation, the moment of confession was characterized by discussions of theatricality-like rivalry, presented as a typical feature of evangelical religious institutions. While Swaggart emphasized personal responsibility ("I have no one but myself to blame," "I am not going to whitewash my sin," and so on [Dart 1988b]), mainstream media assessments tended to treat his confession as a demonstration of Pentecostal evangelism's constant stream of performances, this one distinguished only by its extravagance. "Swaggart should have been nominated for an Oscar in the best actor category this year," said commentator Andy Rooney, for instance (Rooney 1988). In a typical passage, a San Diego Union-Tribune writer also described the confession as a performance "truly worthy of an Oscar."

Rolling his eyes toward heaven and proclaiming with all the firc and brimstone of a modern day Elmer Gantry, Swaggart confessed that he had sinned. . . As the cameras zoomed in for a close-up of Swaggart's tear-soaked, distorted face, he was careful not to wipe even one of those tears away. His voice was a mere whisper as he begged his family's and his Lord's forgiveness. In the picture was his dutiful wile Frances, nodding her pardon, and their son mouthing a tearful "I love you." In the background were white-robed choir members shaking and sobbing. And as the camera panned the congregation, it revealed that many had fallen to their knees in prayer. When it was over, the audience gave the fallen minister a standing ovation (Mandel 1988).

In this narration, Swaggart's confessions and apologies demonstrate not moral recovery but snake-oil evangelist doing shtick for a paying audience.

When, several months later, the comeback-attempt phase of Swaggart's scandal arrivedhe returned to the pulpit against the orders of the Assemblies of God-it was widely reported as another theatrical attempt to "salvage his crippled $\$ 150$ million empire from the wages of his confessed sin" (Harris 1988c). On the pulpit, in the Washington Post account, he was 
"defrocked but defiant," dancing around the stage in "a natty blue suit," exhorting Satan and

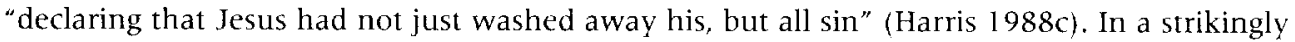
similar Los Angeles Times report, "the golden-haired preacher in the sharp black suit wept, shouted Scripture, spoke in tongues, sang, danced, groveled on his knees, played piano, wept, hugged his weeping wife and told in whispers of dark, prophetic dreams and desperate, latenight conversations with the Lord," launched "into a long sermon about guilt, and why he should no longer feel it," and also "asked for money more than once," concerned with "removing the paralysis that has clutched his \$150-million-a-year ministry" (King 1988a).

Just as the story of Swaggart's sexual transgressions quickly became one of hypocrisy, the hypocrisy revealed became, as the scandal narrative unfolded, an emblematic feature of evangelical institutions: given the financial stakes, media storytelling suggested, televangelists routinely gave performances of morality rather than lived by it. Institutional logic, in fact, made it hard to tell whether you were looking at "holy man or huckster," as Larry King Live put it (CNN 1991b). As The New York Times summed it up, "the Spirit-filled passions that brought men like Mr. Swaggart or Jim Bakker to the top are the very things that could spell their downfall in a competitive world in which too many preachers may be chasing too few dollars" (Applebome 1988). In the end, the mass mediated scandal story became one not of an individual's sexual transgressions, but of an institutional environment that encouraged inauthenticity and thus hypocrisy: a competitive, cutthroat televangelist marketplace in which morally conservative rhetoric and theatricality are rewarded with earthly delights. ${ }^{7}$ In the evangelical religious world revealed in these scandal stories, the gaps between public face and private action, so succinctly and salaciously revealed in Swaggart's Arline Highway visits, are shown to be expected rather than shocking. In this media telling, only the naive ought to be scandalized by a clergyman who does not practice what he preaches.

\section{Hugh Grant: Pure Hollywood}

As with Jimmy Swaggart, movie actor Hugh Grant's televised 1995 confession to sexual indiscretions with a prostitute became the summary moment of his sex scandal. "What the hell were you thinking?" asked Jay Leno on the Tonight Show. "I did a bad thing," Grant said of his arrest at 1:30 a.m. for "lewd conduct" (oral sex, it turned out) with prostitute Divine Brown while parked in his BMW near Hollywood's Sunset Strip. "And there you have it." It was, he had said the day after his arrest, "something completely insane" (Leeds and Touhy 1995). Yet, if for Swaggart visiting a prostitute triggered a discussion of hypocrisy. Grant's encounter elicited not a whisper of such moral outrage. Prostitution and prostitute-visits themselves, moreover, were only rarely subject to moral evaluation; one lone-wolf editorial, for example, complained that media coverage of Grant ignored "the real problems of prostitution," which is both "morally repugnant" and "unhealthy" ("Hugh Grant's Unfunny Crime" 1995). In fact, reports referred only obliquely to the actual sex-referring to the "lewd conduct" charge or generically to "a sex act" or "dallying" ("Prostitute Tells of Tryst" 1995; CBS News 1995a; CBS News 1995c)-except for a brief moment, when Divine Brown sold her story to a British tabloid (including comments about his penis, his fantasies of sleeping with a black woman, and the oral sex she provided) ("Prostitute Tells of Tryst" 1995; Roeper 1995). The sexual encounter, instead, took its place in the storytelling in one of two frameworks: in celebrity-gossip discussions of the Grant-Hurley relationship troubles, as evidence of personal

7. In 1991, the Gorman lawsuit came to trial. Swaggarl was found with another prostitute in California (Castaneda 1991), and new photographs of Swaggart with Murphree were released, and there was a brief revisiting of the scandal. Like the original, this replay was reported primarily as a "sordid feud" (Keen 1991), raising the question of "whether Swaggart cared more about morality or market share" (CNN 1991a). 
disloyalty; and, in the even stronger image-as-commodity frame, as evidence of the gap between a "nice" public image and a "naughty" boy's private self.

In both versions of the storytelling, media coverage began with a bemused puzzlement over risk and motivation. "Why did he do it?" asked CBS, CNN, The San Francisco Chronicle, The Toronto Star, Los Angeles Times, the Minneapolis Star Tribune, People magazine, Larry King, and many others (Ager 1995; CBS News 1995a; Chaudhuri 1995; CNN 1995a; CNN 1995c; Colton and Romero 1995; Schneider 1995; Stein 1995). "Why does a dashing guy like Grant ... pick up a Sunset Boulevard hooker? Why does a guy who could crook his little finger and have half the female population at his disposal opt for a quickie in the front seat?" asked The Washington Post (Roberts 1995; see also Seligmann and Gordon 1995). USA Today put it in even simpler terms. "Why would a heartthrob," the paper asked its readers, "turn to a street hooker" (Thomas and Yancey 1995)?

Various explanations were initially offered: sexual compulsion, the desire for uncomplicated sex, male piggishness, British innocence, the lures of the Hollywood playground, the pressures of fame (Ager 1995; Colton and Romero 1995; Gilbert 1995; Mann 1995; Mansfield 1995; Roberts 1995; Stein 1995). ("Hollywood is predicated on bad behavior. It's almost a job requirement," wrote a Washington Post reporter, beginning a transformation of Grant from an unusual risk-taker to a creature of his Hollywood environment [Mansfield 1995].) Interestingly, however, speculations about why he might have turned to a prostitute quickly gave way (in part preempted by Grant's next-day move to the confessional phase) to questions of impact, as the story took two simultaneous directions: the story of a relationship in trouble, and the story of a career in trouble. It is through the second, in particular, that Grant's story became emblematic of the Hollywood entertainment industry.

Told mainly by entertainment reporters and gossip columnists, one frame considered the Grant-Brown encounter as a trigger for a saga of betrayal and forgiveness. Delivered in the soap-operatic tones characteristic of most entertainment celebrity reporting (Gamson 1994a). reporting speculated on whether or not Hurley would leave Grant (Ehrlich and Kappstatter 1995; Healy 1995), asking readers whether they think she should leave him ("Hugh's Moral Lapse" 1995; Kula 1995), culminating in an interview given by Hurley to Barbara Walters, who asked, "Can she forgive and forget" (ABC News 1995)?

Yet, even within the framework of betrayal and forgiveness were hints of the stronger frame through which this scandal story developed in mainstream media: of a crisis in image management. Hurley herself was, for instance, regularly portrayed as performing, rather than living, the role of hurt girlfriend. "It may be the performance of actress-model Elizabeth Hurley's career," the Phoenix Gazette reported. "Since her boyfriend Hugh Grant was arrested with a Hollywood hooker .. . Hurley has convincingly portrayed the beautiful, betrayed girlfriend to an audience far bigger than any of her previous performances" ("A Career Performance" 1995; see also Roeper 1995). Divine Brown, too, was absorbed into the framework of scandal as celebrity-business opportunity: "peddling panties" in a 30-second Brazilian TV commercial for $\$ 30,000$ (Kennedy 1995) and appearing in a spoof of the milk mustache advertisements in Esquire, she was "using up her fifteen minutes of fame" (Stengel 1995; see also Yancey 1995).

From the beginning, in fact, Grant's sexual act was brought into view primarily as a demonstration of the difficulty of keeping a private self in line with a saleable public image. The image of Grant, derived mostly from his film roles, as a "handsome leading man, best known for playing a shy romantic," "the suave, boyish-looking English star" with "the bashful grin" and "sparkling GQ persona" (Gilbert 1995; Sullivan 1995; Weinraub 1995) was consistently compared against his arrest "with his black pants pulled down to his knees" in "a sleazy section of Sunset Boulevard" (Sullivan 1995; Weinraub 1995). What made Grant's act so extraordinary was not the sexual impropriety but the undercutting of a valuable image, the way the "bizarre arrest," as People's Grant-adorned cover put it, "tarnishes the image of Hollywood's most charming leading man" (Schneider 1995). "On his field trip into the Sunset night," Time 
magazine claimed, "Grant went out of character, played disastrously against type, and punctured a popular illusion. As many moviegoers saw it, he didn't cheat on Hurley so much as he cheated on them" (Corliss 1995, emphasis added; see also Steyn 1995). If Swaggart was the huckster-hypocrite showing his true colors, Grant was the fate-tempting movie star, playing fast and loose with his primary commodity, his publicly-available persona.

Thus, the persistent focus from the day after Grant's arrest was on the impact of the scandal on Grant's career as actor and celebrity, which depended on intricate management of image. An online poll showed that "Hugh Grant's awfully big misadventure on the streets of L.A. may actually help his career" (Gilbert 1995); USA Today wondered about the "effects of the scandal ... on Grant's squeaky-clean career" (Thomas 1995), Newsweek suggested that "the hooker episode could actually improve his image, giving him a bit of a dark side-and quelling rumors that he might be gay" (Seligmann and Gordon 1995), and the Los Angeles Times added that "the consensus in Hollywood is that the damage, if any, will be minimal," since "Grant finds himself at the curious juncture of contemporary celebrityhood where reward and punishment merge" (Walker 1995). Indeed, even the "will they stay together?" storyline was often melted into that of image management, as in this Atlanta Joumal and Constitution column:

What if the issue [of Hurley and Grant's future together] hangs in the balance for a few weeks? Say, until ... "Nine Months" is scheduled to open. During that time, Oprah, Montel, Geraldo, and every local media outlet imaginable conduct a public debate: Should she forgive him? ... Finally, at the premiere of "Nine Months," Hurley and Grant appear together magically. All is forgiven. All is sunshine and lollipops. His charm intact, his virility enhanced, Grant's career skyrockets. . . Everyone lives happily-and wealthily-cver after (Ringel 1995; see also Teitell 1995). ${ }^{8}$

Relationships in the entertainment business, are performances; scandal, managed properly as a publicity tool, is good show business, "a career move," as Time proposed (Corliss 1995).

Indeed, the moments of confession and apology were covered as pure, brilliant spinindeed, such brilliant spin that the scandal's confession and comeback phases collapsed into one another. In a striking parallel to the Swaggart coverage, clothes, his mannerisms, his words, even his hair, were scrutinized and interpreted as public relations maneuvers. The San Francisco Chronicle described the apology as "Hugh-mility, show biz style," in which Grant, "perhaps trying to erase the image of his police booking photo in a striped pullover," wore a "dark blue pinstriped suit" and a "checked pink" tie, "smiled a lot and was fidgety." his hair flopping "all over the place" (Carman 1995). The day after Grant's Tonight Show apology, CBS This Morning gathered a couple of entertainment reporters to answer the question, "how did he do?" ("he seemed very contrite," said one; "the obligatory amount of squirming," said the other) (CBS News 1995b), and the Los Angeles Times reported that Grant, with his "pained hang-dog look" and "the embarrassed face that everyone wanted to see" had "been appropriately remorseful," (Hall 1995; Riemenschneider 1995). This was, The New York Times asserted, "the World Series of Damage Control." The Times called in the city's leading publicists for their post-game assessments. "A great success," said one. "He stayed in character." Another publicist concurred: "He was properly, impishly contrite" (Pogrebin 1995; emphasis added). "Hugh Grant's post-prostitute PR sweep seems to be working like a charm," USA Today reported (Facter 1995); others praised Grant's "miraculous save of his career" (Roeper 1995), his "skillful handling of the media" (CNN 1995b), and his publicist, who earned "high praise for her deft touch in handling the affair (Grant's penitent appearances on TV)" (Mansfield 1995). As Grant moved through "television's stations of the cross," a New York Times commentary claimed, he became more and more a creature of his environment: "a recognizably human leading man had metamorphosed into

8. This cynical statement was actually quite prescient. The week after it was written, in the midst of "should she forgive him" stories, Grant went on his apologetic publicity tour. Grant and Hurley appeared together at the premiere of "Nine Months." 
the bland Hollywood commodity ready to be plugged into the assembly-line" (Rich 1995). Grant became, that is, a better performer, a more typical Hollywood product, through the sex scandal.

The Hugh Grant sex scandal was never a story in which sexual norms per se were much at stake. Mainstream media discourse, in treating the scandal as a story of an image-commodity risked and recuperated, transformed Grant into a symbol of Hollywood's celebrity system; the story of a relationship-risking sexual act was overshadowed by a story of an institution's public image pressures. In a manner that, despite their different forms, resembles Swaggart's story, Grant's behavior became gradually normalized: the focus shifted rapidly from sex to image, the sin from breaking sexual norms to breaking character, the lessons from individual to institutional. A consistency between image and reality, this scandal discourse proposed, was both required and confounded by the entertainment industry; in that kind of institutional environment, the story goes, where an image crisis is always hiding in wait, an actor who is not what he seems to be is expected, and the revelation of the public-private gap through scandal comes to be routine. "Another summer," as one pair of reporters sighed, "another Hollywood scandal" (Leeds and Touhy 1995).

\section{Dick Morris: Political Prostitution}

In August of 1996, in the midst of the Democratic convention, the tabloid Star broke the news that top Clinton adviser, Dick Morris, had been seeing a prostitute named Sherry Rowlands, who reported not only that Morris liked "sucking toes and being dominated," but also the he had bad-mouthed the President ("the Monster") and First Lady ("the Twister"), let her listen on the phone while he spoke with the President, told her of the NASA discovery of life on Mars before it was announced to the public, and let her read a Hillary Rodham Clinton speech before it was delivered (Fee and Raposa 1996; Maraniss and Baker 1996). Discussing Morris' resignation on Larry King Live the next day, the Star reporter who investigated and wrote the piece argued, "this is not just a story of somebody who is having an illicit affair. It's not a story of him betraying the trust of his wife, embarrassing his wife. The story is that he was betraying and embarrassing the President" (CNN 1996d). The Morris scandal unfolded, in fact, as one in which the central relationship was between Morris and Clinton-"the president and the sleazeball," in one commentator's phrasing (Brooks 1996) - and the relationship between Morris and his wife, Eileen McGann, was secondary. "If the Dick Morris scandal were only a story about a presidential adviser who'd been caught in an immoral or embarrassing lapse, it would not have been so unique," an $A B C$ report tellingly asserted. "There have been plenty of such washington lapses over the years. No, this is a story that many people see as one of betrayal, not only of Morris' wife, but betrayal of the President as well" (ABC News 1997a). Much like in the stories from religion and entertainment, as the media coverage progressed, Morris' "fall" was normalized, taking its place as a demonstration not of a bad apple spoiling the bunch, but of an American political environment in which good apples, not bad ones, ought to be the surprise.

As with Swaggart and Grant, there was nothing particularly shocking about Morris' sexual behavior itself, even if it was, as in the other media tales, the source of some fun copy and late-night talk-show punchlines. While tabloid papers and television shows kept the "kinky sex, including toe-sucking and dominance" details alive ("Top Strategist Quits" 1996), neither tabloid nor mainstream coverage focused much attention on the morality of prostitute visits or extramarital sex, at least not as discrete or remarkable normative violations. ${ }^{9} \mathrm{CNN}$ 's lead into the story, for instance, first mentioned allegations "that Dick Morris allowed a woman to listen in on conversations he had with the White House, and also allowed her to read an advance copy of the speech given by Hillary Clinton," only later mentioning that the woman 
in question was a prostitute; even then, the "big question" concerned not sexuality or sexual norms, but "how all of this will affect the President, how it will affect his campaign" (CNN 1996b). As told primarily by political reporters, the sexual behavior instead initiated a story of disloyalty and hubris, positioned with the larger institutional framework of politics as a game, in which "spin" trumps belief. Whatever the outcome, media reports implied and asserted, this scandal revealed politics as usual.

Like much political campaign reporting, which tends to focus, horse-race style, on how one event or another affects a candidate's odds (Bennett 1996; Littlewood 1999), media coverage focused immediately on the impact on Clinton's campaign. The "timing was incredibly bad" (Lambrecht 1996), overshadowing the President and "tossing a big blob of mud on what should have been the shining climax to Clinton's nominating convention" (Ball 1996)-perhaps "a set-up" "carefully orchestrated to embarrass the President" (CBS News 1996), but cer tainly "a major distraction" (MacNeil/Lehrer 1996), a "bombshell for the campaign" (CNN 1996a) a "public relations disaster" (ABC News 1996) that detracted from "an otherwise successful effort to capture favorable publicity" (Fritz 1996). And it could not help that "the central force behind the emphasis on family values" was caught with a call girl (Berke 1996), providing a "counterpoint to the convention's focus on cherishing children and strengthening families-a Morris-drafted script" (Page and Nichols 1996). (Interestingly, the hypocrisy theme was weaker than in Swaggart's case, and the related public-private gap theme weaker than in Grant's, suggesting, perhaps, that expectations of integrity are weaker among journalists covering politics.)

In this framework, it was the revival of the "questions about Clinton's own personal behavior that have dogged him" - the "character issue" - that threatened the campaign (Page and Nichols 1996). Morris "revived the enduring question about whether Clinton stands for what he stands for," Time suggested (Lacayo 1996). He did so, according to most media storytelling, in part by echoing Clinton's alleged sexual pursuits with his own, but even more so by revealing not just sexual but ideological and political promiscuity. From the day the story broke, Morris was routinely characterized as an "unprincipled hired gun" (Lambrecht 1996), an "amoral creep" (R. Cohen 1996) selling himself to the highest bidder, a "switch-hitting consultant" (Ball 1996) with "a devotion to tactics and the game that seemed to be unmoored to ideology or party" (Mitchell 1996), a "chameleon ... known to blend in his political coloration with the color of his paycheck" (Flynn 1996), a "brilliant and sometimes arrogant strategist with little partisan loyalty" (Bayer 1996), a "political mercenary" (ABC News 1996), "a man with no compass or beliefs" (Borger 1996a), an "opportunist who had no compunction about switching back and forth between the Democratic and Republican parties" (Fritz 1996). "As far as I'm concerned," as author Larry Sabato summed it up for People magazine, "there were two whores in that [Jefferson] hotel room" (Howe 1996).

Clinton's "character," the reports repeated, was being judged at least in part by the company he chose to keep-and that company was unprincipled, disloyal, and amoral. "A lot of people are going to say," suggested CNN's Bobbie Battista, "How can the president have hired a man like that" (CNN 1996b)? "The problem is that [Clinton] knew exactly who Morris was and still chose to rely on him," a US News $\theta$ World Report columnist argued (Borger 1996a). "The problem," the Wall Street Journal's Paul Gigot suggested on PBS, "raises questions about political judgment and political sincerity. The judgment is about who a President, any President, any candidate, surrounds himself with" (MacNeil/Lehrer 1996; see also R. Cohen 1996). Within this frame, the fact of a married man visiting a prostitute was

9. It is revealing, in fact, that in an attempt to manage the scandal, the Clinton campaign reasserted a narrow sexual morality frame, saying that "The president is obviously against the crime of prostitution" (Lardner and Harris 1996)-a frame that never took. On Larry King Live in September, Star editor Dick Gooding complained that Clinton advisor James Carville "wants to make this just a sex story" (CNN 1996d, emphasis added). 
just one small piece of evidence of rottenness-and reports repeatedly underlined this through the assertion that the transgression was not sexual immorality but the telling of White House secrets.

If the revelations of Morris' loose sexual ethics, and even more of his willingness to breach White House rules in order to impress a woman, demonstrated Morris' amoral character, his post-revelation behaviors were brought in as final proof. Having first refused to "dignify" the "sadistic vitriol of yellow journalism," Morris resigned, in what appeared to be a quick, steep fall, and issued a public apology to his wife (Berke 1996). Within days, however, the comeback phase of his scandal story had begun: he was on the cover of Time magazine for the second week in a row, albeit for a less flattering article then that of the prior week, and signed a lucrative book deal. "How the fallen have risen," said The New York Times two weeks after Morris" resignation (Bennet 1996). "Dick Morris' term as a political pariah," the Washing. ton Post reported, "seems to have lasted about an hour and a half" (Streitfeld 1996). ${ }^{10}$ This "comeback" - the first of two-became further evidence in the story of Morris" disloyalty and shamelessness, the "blab-book deal Morris negotiated for Random House" another "obvious betrayal" (Oliphant 1996), "the payoff to this immorality tale" (Peyser 1996), its pre-publication another "Morris-style machination" (Purdum 1997), its contents a violation of "the minimum moral requirements of loyalty" (Borger 1996b).

Most revealingly, in a parallel to Swaggart and Grant, the story had become even more firmly focused on those traits not only as individual character flaws, but as role behaviors rewarded by political institutions, and particularly of politics guided by teams of "consultants." Morris became, through the revelation and especially through the comeback phase, the quintessential political consultant, a symbol of politics-as-game. Now, instead of consulting for the President, he was consulting for himself, becoming, as. The New York Times characterized it, "his own client" (Mitchell 1996). "The day after he was forced to resign from Clinton's inner council because of a sex scandal," USA Today reported, "he was spinning his story to a news magazine" (Page 1996); soon after, we see him turning "a political-science classroom at New York University into a major political event in his campaign to rehabilitate his image" (Estrich 1996). Although the tone was different-less exoticizing than the Swaggart coverage, less jokey than the Grant coverage-this theme of Morris' comeback-as-performance closely resembles the narration of the Swaggart and Grant scandals. Morris was, as the story was told, "engineering another comeback: his own" (Page 1996), using his well-honed manipulation skills to "save himself" (Estrich 1996) and "keeping his name in lights" (R. Cohen 1996), "trying to mastermind his own resurrection, even as others proclaim him finished" (Mitchell 1996). CNN's "Inside Politics" even awarded Morris its capstone Political Play of the Weekfor "masterminding his own comeback" (CNN 1996c).

Morris, argued writer David Brooks, was "thoroughly politicized": he "turned his own marriage into a grotesquerie in order to save his political skin," posing for a "homey' dinner table picture in Time with his wife," who herself offered a statement that sounded like "a focus-group-tested paean to adulterers." How, Brooks asked, "could a totally politicized consultant in this atmosphere not devolve into an unnatural creature, beyond shame and plausibility" (Brooks 1996)? As Morris' "amoral" behavior came to be seen as a feature of politicsby-consulting, even the secret-spilling, President-eavesdropping, toe sucking visits to a prostitute became, in retrospect, similarly emblematic of the institutions of politics. Adultery and

10. Morris, revising the usual sequence, saved his more elaborate mea culpa phase for a series of talk-show appearances months later, coinciding with the release of his book (CNN 1997; ABC News 1997a; ABC News 1997b). The story he told was, not surprisingly, quite different from that told about him at the height of the scandal; of individual failings and sexual addiction. "I had a fundamental tlaw in my character," he told ABC's Good Morning America. Hc led a double life, one of "the daytime," and the other the "hidden life . . of sexual promiscuity" (ABC News 1997a; see also CNN 1997). His book was published to mixed reviews in 1997, and Morris has continued a successful career as a writer and political pundir (Moore 2000). 
prostitution visits were objectionable not so much as sexually immoral acts, but as reminders that American politics rewards amorality and untrustworthiness. Morris' "train wreck," wrote a Time columnist, "compounded by his ideological promiscuity, adds to the widespread public suspicion that it takes an unwholesome personality-a professional liar or a power fetishistto go into politics in the first place" (Morrow 1996). To be "politicized" may encourage amorality, this dominant trame suggested; in politics, it may be normal to be an "unnatural creature," and Morris' story summarized that lesson. Although it began with the tabloid-driven sexual story, in the hands of mainstream political reporting it became a story of politics as usual. The scandal was not how unusual a character was Dick Morris, but how representative he was of American politics.

\section{Sex Scandal Narratives: Sexuality, Institutional Moralities and Media Behaviors}

The three cases recounted and analyzed here do not, of course, tell us finally about all media-conveyed sex scandal discourse, but they do provide fresh illumination. They suggest, first of all, that the reinforcement of sexual norms and ideologies, while certainly a contribution of sex scandals, is not their primary one. It would be overstating the case to suggest that sex scandal narratives are not really about sex; it is, after all, sexual behaviors and not, say, unusual eating or parenting behaviors, that so regularly stir scandal. Sex scandal narratives certainly do, on a general level, reveal sexual values directly - and even more so indirectly, through the "cultural givens" (Binder 1993; Schudson 1989) regarding sexual behavior their storytellers take for granted. For instance, despite their differences, the three cases here take for granted and reproduce a relatively cavalier, if conflicted, attitude towards prostitution, proceeding with the background assumption that the purchase of sexual services by men is both shameful and understandable; they take for granted, that is, a familiar gendered sexual order. The women whose sexuality was for rent were dismissed or further objectified in the storytelling (largely erased from the mainstream media stories, Murphree, Brown, and Rowlands were relegated to tabloid and pornographic press). while the men who purchased sexual services were located in a masculine world in which prostitute visits were often narrated as demonstrations of manhood (Gamson 2001). Within the larger discourse of masculine sexuality assumed in the storytelling, men were sexual subjects, the relationships between men were central, and manhood reaffirmed by naughty-boy transgression: Morris was "Bill's Bad Boy" (Bayer 1996); Grant, aided by a ribbing Jay Leno, put to rest rumors of sissyhood and homosexuality; Swaggart and Gorman competed for wealth and power, their sexual relationships with women one tool in their warrior arsenal. ${ }^{11}$

Still, while scandal stories rely on and reproduce assumptions about gendered sexuality, there are excellent reasons to doubt that the communication of sexual values is their distinct and primary cultural contribution. As it does in other public discussions (Gamson 1999; Rubin 1993), sexuality takes its place in these morality tales more as symbol and vehicle than as topic. To begin with, the same sexual action yielded not a singular narrative of sexual morality, but narratives whose themes and characters-hypocrisy, recklessness and amorality; the charlatan, the daredevil, the mercenary-both varied according to different institutional settings and extended far beyond the morality of commercial or "adulterous" sex, suggesting a process more complex than the transmission of collective sentiments about appropriate sexual behavior. Even the sexual act that gave rise to each case received strikingly little attention as a

11. It seems unlikely, for instance, that the same sort of scandal script operated in narratives featuring "non-masculine" men such as George Michael, Pee Wee Herman, or Michael Jackson (Erni 1998). In those cases, where assumptions about the relationship between masculinity and sexuality were disrupted, the scandal was likely more directly focused on sexual norms and less on institutional expectations. 
transgression of sexual morality per se, and dropped out of discussion rather quickly. If a character was common to all of them, in fact, it was less the sexual cad than the confidence man, a longstanding cultural figure who, as one 19th century advice manual put it, for instance, was found "putting on false appearances," his "language and conduct" proceeding not from "fixed principle and open hearted sincerity but from a spirit of duplicity and management" (quoted in Halttunen 1982:33). If a theme united them, it had less to do with sex than with inauthenticity: revelations of stark contrasts to the professed persona, confessions that were staged performances rather than cleansing repentances, comebacks achieved through effective spin rather than forgiveness. Sexual transgression was hardly the central drama here.

The surprising element of these scandals is not just the relative quiet of sexual themes in these scandals, or just their common distrust of public faces, but the theme of institutional decay that got louder as the media storytelling progressed. Sexual stories were edged out by stories of public institutions-of how evangelical institutions work, how the entertainment industry operates, how political games are played. These institutional frames were geared toward making sense of the lack of integrity demonstrated in scandal: they suggested that personal behavior at first presented as "shocking"-the hypocrisy or recklessness or disloyalty revealed in the encounter with a prostitute-may be quite typical of those in the institutional role, that the individual nonconformity to sexual norms may actually reveal a sort of conformity to institutional norms. Public institutions, each story's dominant frame suggested, demand and reward performances that they make difficult to maintain, encouraging inauthentic role-playing and increasing the chances that public personae will turn out to contradict private selves. Given how religion, entertainment, and politics really work, these stories suggested, scandal is always already there, waiting to show itself.

Given the well-documented penchant in American culture, and especially in American media, for individualist rather than structural frames, and personal rather than institutional storytelling (Bennett 1996; Iyengar 1991; Bellah, et. al. 1985), and given the over-determined status of sexuality as "personal," such a narrative dynamic is especially striking. Why, in these cases, do we find this unusual narrative reversal? Although there is certainly evidence that American cynicism about institutions has increased, especially in the post-Watergate yearsand scandals certainly circulate and emphasize such cynicism-it seems unlikely that what we are witnessing, in these cases, is a sudden eschewing of both individualism and sexual content by American citizens. The dynamics encountered here-the interest in and then backing-off from sexual discussion, the focus on the common falsity of public images, and especially the rapid movement toward the framework of institutional pathology-are best understood, I propose, through an analysis of media organizational interests and behaviors. The institutional frame solves quite a few problems for mainstream media organizations-especially their simultaneous need for both sensationalism and legitimacy - and serves reporters' interests in getting their story prominent placement as "hard" rather than "soft" news.

Sexual stories present both an opportunity and a challenge for mainstream news organizations: an opportune shortcut to larger audiences that poses threats to legitimacy. Sex, among other forms of "sensationalism," is widely acknowledged among commercial media producers to be a means to attracting readers and viewers (Bennett 1996), and news organizations of all kinds therefore have an obvious competitive interest in telling sexual stories. Yet mainstream news organizations also rely, for their survival, on the perception that they are not simply purveyors of sexy sensation, but of credible, reliable and necessary information (Gans 1979). As market forces pushed mainstream news organizations toward the topics and presentation strategies of tabloid publications and tabloid television in recent years (Gamson 1994b), this tension has become even more pronounced, as mainstream media organizations increasingly court the charge that they are more like tabloids than unlike them. It is this context in which contemporary sex scandal stories are told, and that steers the storytelling away from sexual details and towards news frames that focus on institutions. The degree of institutional critique may be tempered by social proximity, as in the case of entertainment, in which 
reporters and industry workers are tightly aligned (Gamson 1994a), or heightened by social distance, as in the case of religion, in which reporters and religious institutions have historically stood in tension (Silk 1995). But across the different settings, by framing the sex scandal as an institutional morality tale, the news organization retains both credibility and, literally, sex appeal, offering audiences "public service" (instructions on how and why public images are not to be trusted) that justifies the appeal to sex, and a social significance (the moral failings of institutions) that marks these stories as legitimate and newsworthy.

The institutional framework is pushed along by internal media organizational processes as well. Its logic dovetails with reporters' pursuit, long since routinized into practices, of professional legitimacy. The division of news into a hierarchy from "hard" news to "soft," human-interest stories (Tuchman 1978:47-48), and the correspondence of those categories to particular news "beats" (Gans 1979), generates a struggle for professional status in which prestige is derived from a story that is both long-lasting and "hard." (A study of religion reporters, for instance, found that "placement in sections outside the identified religion section ... or placement in the news section of the paper, is the most sought-after" [quoted in Hoover 1998:73].) Some journalists are better positioned in that struggle than others: the politics beat produces mostly hard news by definition, and both entertainment and religion tend to be considered soft beats (Gamson 1994a; Hoover 1998). It is no accident, for instance, that the case with the least institutional focus (Hugh Grant) was also the one least successful at moving from its more limited, lower-status placement (entertainment sections of newspapers, magazines, and television programs) to a position of greater stature-and also no accident that the attempt to lend the case significance through an institutional framing was nonetheless pursued. The narrative push toward institutions is one strategy for "hardening" and lengthening what is, on the face of it, a "soft," short-lived, and lower-status story.

The resulting distancing of sexual discussion, and intensified attention to the institutional roots of individual pathologies, is a striking exception to the usual American media habit of individualist reasoning. It is also, in a broader sociological sense, theoretically provocative. Sociologists, drawing on Durkheim, are accustomed to thinking of public stories of transgression, sin, or deviance as reminders about society-wide norms for individual action (Durkheim 1982 [1895]; Erikson 1968). Indeed, the small body of theoretical literature approaching scandals sees them mostly as stories of "individuals who privilege their personal desires over the rules of society," which thereby provide "the most extreme example of how, in practice, individuals are held to an imagined, idealized standard of social conduct" (Lull and Hinerman 1997:29, 5). These scandals move far past the narrative of the individual sinner, whose normative violation is painted as atypical and underlines what must not be breached; here, it is the institution's moral universe. as much or more so than the individual's character, that is revealed to be rotten. Structured largely by media organizational interests, they remind their witnesses not of normative order but disorder, not of what they believe, but of what cannot be believed. As such, they provide an unusual addition to understanding how norms circulate culturally: rather than proving the normal with the deviant, mass-mediated scandals show the perversions of American institutional habitats, which, in the end, seem to make the sinner more normal than not.

\title{
References
}

\author{
ABC News \\ 1995 "20/20: Questions for Elizabeth" (August 4). \\ ABC News \\ 1996 \\ ABC News \\ "Nightline: Speaks to Democrats amid Morris scandal" (August 29). \\ 1997a "Good Morning America: Dick Morris interview" (January 16).
}


ABC News

$1997 \mathrm{~b}$ "Prime Time Live: Interview with former Clinton Advisor Dick Morris" (January 15).

Ager, Susan

1995 "Hugh Grant just looking for a quick fix." The Toronto Star (July 6):C6.

Anger, Kenneth

1975 Hollywood Babylon. New York: Dell.

Applebome, Peter

1988 "Swaggart's troubles show tension of passion and power in TV evangelism." The New York Times (February 28):A30.

Ball, Karen

1996 "Aide quits in sex flap tale of trysting." New York Daily News (August 30):5.

Basch, Norma

1993 "Marriage, morals, and politics in the election of 1828." Joumal of American History 80:890-918.

Bayer, Amy

1996 "Sex scandal rocks campaign." The San Diego Union-Tribune (August 30):Al.

Bellah, Robert, William Sullivan, Ann Swidler, and Steven Tipton

1985 Habits of the Heart. Berkeley, CA: University of California Press.

Bennet, James

1996 "For fallen Clinton aide, forum for ethics lecturc." The New York Times (September 13):A22.

Bennett, W. Lance

1996 News: The Politics of Illusion. 3rd ed. Whitc Plains, NY: Longman.

Berke, Richard L.

1996 "The Democrats: The resignation." The New York Times (August 30):Al.

Berry, Jason

1992 Lead Us Not Into Temptation: Catholic Priests and the Sexual Abuse of Children. New York: Doubleday.

Binder, Amy

1993 "Constructing racial rhetoric: Media depictions of harm in heavy metal and rap music."

American Sociological Review 58:753-767.

Borger, Gloria

1996a "The company he keeps." U.S. News World Report (September 9):20.

Borger, Gloria

1996b "Singing a song of himself." U.S. News World Report (September l6):62.

Bourdieu, Pierre

1984 Distinction: A Social Critique of the Judgment of Taste. Cambridge, MA: Harvard University Press.

Brooks, David

1996 "Dick Morris: Alive and well in the solipsism zone." The Weekly Standard (September 16):27.

Carman, John

1995 "Hugh Grant eats crow on 'The Tonight Show." The San Francisco Chronicle (July 1 1):E1.

"A Career Performance"

1995 The Phoenix Gazette (July 4):A2.

Castaneda, Carol

1991 "Evangelist Swaggart teeters in scandal." USA Today (October 15):4A.

Castor, Laura

1991 "Did she or didn't she: The discourse of scandal in the 1988 U.S. Presidential campaign." Genders :62-76.

CBS News

1995 a "Hugh Grant arrested for lewd conduct with a prostitute" (June 28).

CBS News

1995b "Michael Fleming and Jess Cagle discuss actor Hugh Grant" (July 11).

CBS News

1995c "Negative opinions of Hugh Grant's personal character affect the opinions of his first Hollywood movie" (July 19).

CBS News

1996 "President Clinton's key political strategist Dick Morris resigns" (August 29).

Charmaz, Kathy

2000 "Grounded theory." In Handbook of Qualitative Research. Norman K. Denzin and Yvonna S.

Lincoln, eds.. 509-535. Thousand Oaks, CA: Sage. 
Chaudhuri, Anita CNN

1995 "Making sense of Hugh Grant's misadventure." Minneapolis Star Tribune (June 30):3E.

1991 a "CNN specials." (June 27).

$1991 b$ "Larry King Live: More on the Jimmy Swaggart scandal." (June 27).

1995a "Showbiz Today: Hugh Grant returns to England amid sex scandal." (June 30).

1995b "Showbiz Today: Hugh Grant spin control works wonders at box office." (July 17).

1995c "Larry King Live: Hugh Grant talks about his arrest" (July 12).

1996 a "Clinton administration forced into damage control mode." (August 29).

1996 b "Democratic strategist discounts effect of Morris story." (August 29).

1996c "Inside politics: Morris' brashness earns him play of the week." (September 6).

1996 d "Larry King Live: Dick Morris resigns over alleged call-girl scandal." (September 29).

1997 "Larry King Live: Dick Morris tells all." (January 16).

Cohen, Richard

1988 "Swaggart and that other sin." The Washington Post (February 26):A23.

Cohen, Richard

1996 "A betrayal of confidence." The Washington Post (September 5):A23.

Cohen, William A.

1996 Sex Scandal: The Private Parts of Victorian Fiction. Durham, NC: Duke University Press.

Collins, Gail

1998 Scorpion Tongues: Gossip. Celebrity, and American Politics. New York: William Morrow and Company, Inc.

Colton, Michael and Dennis Romero

1995 "Grant's arrest leaves many wondering 'Why?" Los Angeles Times (June 30):E 1.

Corliss, Richard

1995 "Hugh and cry." Time (July 24):58-59.

Dart, John

1988a "Swaggart steps down after public confession." Los Angeles Times (February 22):Al.

Dart, John

1988b "A twist of fate." Los Angeles Times (March 5):B6.

"Debbie Does Swaggart"

1988 Penthouse (July):107-122.

Durkheim, Emile

1982

[1895] The Rules of Sociological Method. New York: Free Press.

Ehrlich, Dan and Rob Kappstatter

1995 "Take it for granted, she walks out on Hugh." New York Daily News (July 3):3.

Erikson, Kai

1968 Wayward Puritans. Boston: Allyn and Bacon.

Erni, John Nguyet

1998 "Queer figurations in the media: Critical reflections on the Michael Jackson sex scandal."

Critical Studies in Mass Communication 15:158-180.

Estrich, Susan

1996 "Comeback Kid' for real." Los Angeles Times (December 15):M2.

Facter, Sue

1995 "Hollywood grants Hugh forgiveness." USA Today (July 13):2D.

Fee, Gayle, and Laura Raposa

1996 "Call girl says Clinton top aide a strange bedfellow." The Boston Herald (August 29):6.

Fine, Gary Alan

1997 "Scandal, social conditions, and the creation of public attention: Fatty Arbuckle and the

'Problem of Hollywood.'" Social Problems 44:297-321.

Fisher, Trevor

1995 Scandal: The Sexual Politics of Late Victorian Britain. Phoenix Mill, UK: Alan Sutton Publishing. Flynn, Adrianne

1996 "Clinton aide leaves amid sex scandal." The Arizona Republic (August 30):A1.

Fox, Richard Wightman

1999 Trials of Intimacy: Love and Loss in the Beecher-Tilton Scandal. Chicago, IL: University of Chicago Press. 
Fritz, Sara

1996 "Clinton strategist resigns in flap." Los Angeles Times (August 30):Al.

Gamson, Joshua

1994a Claims to Fame: Celebrity in Contemporary America. Berkeley, CA: University of California Press.

1994b "Incredible news." The American Prospect 19:28-35.

1999 "Taking the talk show challenge: Television, emotion, and public spheres." Constellations 6.

2001 "Jessica Hahn, media whore: sex scandal icons and female publicity." Critical Studies in Media Communication (forthcoming in June issue).

Gans, Herbert J.

1979 Deciding What's News. New York: Vintage.

Gilbert, Matthew

1995 "Four Weddings' but no funeral for lewd Hugh." The Boston Globe (June 29):65.

Gitlin, Todd

1983 Inside Prime Time. New York: Pantheon.

Glaser, Barney, and Anselm Strauss

1967 The Discovery of Grounded Theory. Chicago. IL: Aldine.

Griswold, Wendy

1987 "The fabrication of meaning: Literary interpretation in the United States, Great Britain, and the West Indies." American Journal of Sociology 92:1077-1117.

Hackett, George

1988 "A sex scandal breaks over Jimmy Swaggart." Newsweek (February 29):30.

Hagood, Wesley O.

1995 Presidential Sex: From the Founding Fathers to Bill Clinton. Secaucus, NJ: Citadel Press.

Hall, Carla

1995 "Hugh Grant gets fine, probation on misdemeanor." Los Angeles Times (July 12):B 1.

Halttunen, Karen

1982 Confidence Men and Painted Women. New Haven, CT: Yale University Press.

Harris, Art

1988a "Jimmy Swaggart and the snare of sin." The Washington Post (February 24):C1.

1988 b "The P.I. on Swaggart's Trail." The Washington Post (April 13):B1.

1988c "Swaggart's Spirited Return." The Washington Post (May 23):Cl.

Harris, Art and Jason Berry

1988 "Jimmy Swaggart's secret sex life." Penthouse (July):104-106, 123-126, I 38-142, 176.

Healy, Orla

1995 "Liz tells pal her night with Hugh was 'hellish.'" New York Daily News (July 13):3.

Hoover, Stewart $M$.

1998 Religion in the News. Thousand Oaks, CA: Sage Publications.

Howe, Rob

1996 "Man on the spot." People Weekly (September 16):207.

"Hugh Grant's Unfunny Crime"

1995 The Tampa Tribune (July 13):10.

"Hugh's moral lapse sets off some howls of outrage, but just a few say, 'Tut-tut.'"

1995 The Detroit News (July 8).

"The human comedy"

1988 Los Angeles Times (Fcbruary 23), Part 2:6.

Israel, Kali

1997 "French vices and British liberties: Gender, class, and narrative competition in a late

Victorian sex scandal." Social History 22:1-26.

Isikoff, Michael and Art Harris

1988 "Swaggart is focus of adultery investigation." The Washington Post (February 20):Al1. Iyengar, Shanto

1991 Is Anyone Responsible? How Television Frames Political Issues. Chicago: University of Chicago Press. Jacobs, Mark D.

1998 "Scandals as normal crises of political culture." Paper presented the Annual Meeting of the American Sociological Association, San Francisco, CA.

Keen, Judy

1991 "Swaggart vs. Gorman." USA Today (July 8):2A. 
Kennedy, Helen

1995 "You can look divine, keep man hooked: Ad." New York Daily News (August 1):25.

King, Peter $\mathrm{H}$.

1988 "What's past is past. "Los Angeles Times (May 23):A l.

King, Wayne

1988a "Church orders 2-year rehabilitation for Swaggart." The New York Times (February 23):A20.

King, Wayne

1988b "Swaggart says he has sinned." The New York Times (February 22):Al.

Kohn, George C.

1989 Encyclopedia of American Scandal. New York: Facts on File.

Kula, Geoffrey

1995 "Readers to supermodel: Dump Grant." The Boston Herald (July 12):39.

Lacayo, Richard

1996 "Skunk at the family picnic." Time (September 9):24-30, 32-33.

Lambrecht, Bill

1996 "Morris fallout expected to have little effect on Clinton." St. Louis Post-Dispatch (August

30): $14 \mathrm{~A}$.

Lardner, George and John Harris

1996 "Dick Morris may testify on FBI files." The Washington Post (September 7):A6.

Leeds, Jeff and William Touhy

1995 "Another summer, another sex scandal." The Houston Chronicle (June 28):A4.

Littlewood, Thomas

1999 Calling Elections: The History of Horse-Race Journalism. South Bend, IN: University of Notre Dame Press.

Lull, James and Stephen Hinerman

1997 "The search for scandal." In Media Scandals, James Lull, and Stephen Hinerman, eds., 1-33. New York: Columbia University Press.

MacNeil/Lehrer Productions

1996 "The News Hour with Jim Lehrer: Campaign shake-up, sex and politics." (August 29).

Mandel, Whitney

1988 "Swaggart deserves an Oscar." The San Diego Union-Tribune (March 12):B 15.

Mann, Judy

1995 "Getting to the top by reaching bottom." The Washington Post (June 30):E3.

Mansfield, Stephanie

1995 "Scandal? In Hollywood, it's show biz as usual." The Washington Post (July 17):Bl.

Maraniss, David and Peter Baker

1996 "President's Chief Political Adviser quits." The Washington Post (August 30):Al.

Marszalek, John F.

1997 The Petticoat Affair: Manners, Mutiny, and Sex in Andrew Jackson's White House. New York: Free Press. McMichael, William $\mathrm{H}$.

1997 The Mother of All Hooks: The Story of the U.S. Navy's Tailhook Sandal. New Brunswick, NJ:

Transaction Publishers.

Merry, Sally Engle

1984 "Rethinking gossip and scandal." In Toward a General Theory of Social Control. Donald Black, ed., 271-301. Orlando, FL: Academic Press.

Mitchell, Alison

1996 "The consultant." The New York Times (September 2):A10.

Mohr, John W.

1998 "Measuring meaning structures." Annual Review of Sociology 24:345-370.

Moore, Martha

2000 "One-time Clinton power broker emerges unbroken." USA Today (August 16):6A.

Morrow, Lance

1996 "Does the Morris thing matter?" Time (September 9):78.

Oliphant, Thomas

1996 "The rise and fall of the Morris myth." The Boston Globe (September 8):D7.

Page, Susan

1996 "Now, Morris wants to be the comeback kid." USA Today (December 11):8A. 
Page, Susan and Bill Nichols

1996 "Morris flap angers President." USA Today (August 30):1A.

Peyser, Marc

1996 "A strategist of his own fall." Newsweek (November, special edition):12.

Pogrebin, Robin

1995 "The World Series of damage control." The New York Times (July 16):4.

"Prostitute tells of tryst with actor"

1995 The Atlanta Journal and Constitution (July 2):6D.

Purdum, Todd

1997 "Fallen adviser says he is still welcomed by White House." The New York Times (January 11):A7.

Rich, Frank

1995 "Scandal for profit." The New York Times (July 26):A19.

Riemenschneider, Chris

1995 "Actor Hugh Grant 'fesses up to Leno on Tonight Show'" Los Angeles Times (July 11 ):Bl.

Ringel, Eleanor

1995 "Take nothing for Grant-ed in a scandal in Movieland." The Atlanta Journal and Constitution (July 3):7C.

Roberts, Roxanne

1995 "What's the matter with Hugh?" The Washington Post (June 28):Cl.

Roeper, Richard

1995 "Hugh Grant fallout turns to stardust." Chicago Sun-Times (August 9):11.

Rooney, Andy

1988 "Most television evangelists are con men." The San Diego Tribune (March 4):B8.

Rosellini, Lynn

1988 "Why did Jimmy Swaggart yield to temptation." U.S. News and World Report (March 7):62.

Rubin, Gayle

1993 "Thinking sex: Notes for a radical theory of the politics of sexuality." In The Lesbian and Gay Studies Reader, Henry Abelove, Michele Aina Barale, and David Halperin, eds.. 3-44. New York: Routledge.

Ryan, Gery W., and H. Russell Bernard

2000 "Data management and analysis methods." In Handbook of Qualitative Research, Norman K. Denzin, and Yvonna S. Lincoln, eds., 769-802. Thousand Oaks, CA: Sage.

Schneider, Karen S.

1995 "A night to remember." People Weekly (July 10):50-54.

Schudson, Michael

1976 "Sex scandals." In Our National Passion: 200 Years of Sex in America, Sally Banes, Sheldon Frank, and Tom Horwitz, eds., 41-57. Chicago: Follett Publishing.

Schudson, Michael

1989 "The sociology of news production." Media, Culture, and Society 1 1:263-282.

Schwartz, John

1988 "Jimmy Swaggart: Breaking away." Newsweek (April 11):6.

Seligmann, Jean and Jeanne Gordon

1995 "A drive-by scandal." Newsweek (July 10):54.

Silk, Mark

1995 Unsecular Media: Making News of Religion in America. Urbana: University of lllinois Press.

Snow, David, E. Burke Rochford, Steven Worden, and Robert Benford

1986 "Frame alignment processes, mobilization, and movement participation." American

Sociological Review 51:464-481.

Stake, Robert E.

2000 "Case studies." In Handbook of Qualitative Research. Norman K. Denzin, and Yvonna S. Lincoln, eds., 435-454. Thousand Oaks, CA: Sage.

Stein, Ruthe

1995 "The big question: 'Why did you do it, Hugh?'" The San Francisco Chronicle (June 28):El.

Stengel, Catherine

1995 "Brown enjoying her fleeting fame." The Tampa Tribune (August 27):3.

Stepp, Laura Sessions

1988 "Swaggart falls spur discussion of sex." The Washington Post (April 11):A3. 
Steyn, Mark

1995 "Hugh embarrassment." The American Spectator (September):38-39.

Stoker, Laura

1993 "Judging presidential character: The demise of Gary Hart." Political Behavior 15:193-223.

Streitfeld, David

1996 "Publishing: Dick Morris signs deal for book on Clinton race." The Washington Post (September 5):Cl.

Sullivan, Paul

1995 "Hugh caught with his pants down." The Boston Herald (June 28): 1.

Summers, John

2000 "What happened to sex scandals? Politics and peccadilloes, Jefferson to Kennedy." Journal of American History (December): 1-33.

"Swaggart led sex-crazed secret life, prostitute claims"

1988 The San Diego Union-Tribune (February 25):Al.

Teitell, Beth

1995 "Spin doctors offer cures for Hugh Grant's image." The Boston Herald (June 29):37.

Thomas, Karen

1995 "Hugh charged." USA Today (June 30):2D.

Thomas, Karen and Kitty Bean Yancey

1995 "Hugh Grant faces lewd conduct charge." USA Today (June 28):1D.

Thompson, John B.

1997 "Scandal and social theory." In Media Scandals, James Lull, and Stephen Hinerman, eds., 34-64. New York: Columbia University Press.

"Top Strategist quits campaign amid reported sex scandal."

1996 The Detroit News (August 30):Al.

Tuchman, Gaye

1978 Making News. New York: Free Press.

Vaughan, Diane

1999 "Signals and interpretive work: The role of culture in a theory of practical action." Paper

Walker, Michael presented at Toward a Sociology of Culture and Cognition Conference, Rutgers University.

1995 "The Hughman factor." Los Angeles Times (July 10):Fl.

Weinraub, Bernard

1995 "What's the Hollywood topic? Hugh Grant's future, mainly." The New York Times (June 29):C16.

Yancey, Kitty Bean

1995 "Esquire" milks Brown in a 'Dubious' Spoof." USA Today (December 14):2D. 